\title{
BAHASA PRASANGKA SOSIAL DALAM CERPEN “CLARA” KARYA SENO GUMIRA AJIDARMA
}

\section{SOCIAL PREJUDICE LANGUAGE IN SHORT STORY "CLARA" BY SENO GUMIRA AJIDARMA}

\author{
A. Yusdianti Tenriawali \\ Universitas Iqra Buru \\ Jalan Prof. Dr. H. A.R. Bassalamah, SE., M.Si. \\ Namlea, Buru, Indonesia \\ Pos-el: tenriawali@gmail.com
}

\begin{abstract}
Abstrak
Penelitian ini membahas tentang bahasa prasangka sosial dalam cerpen "Clara" karya Seno Gumira Ajidarma. Bahasa yang mengandung prasangka juga terdapat dalam karya sastra. Karya sastra sebagai karya imajiner biasanya menawarkan berbagai permasalahan manusia dan kemanusiaan, hidup dan kehidupan. Pengarang menghayati berbagai permasalahan tersebut dengan penuh kesungguhan yang kemudian diungkapkan kembali melalui sarana fiksi sesuai dengan pandangannya. Fiksi menceritakan berbagai masalah kehidupan manusia dan interaksinya dengan lingkungan dan sesama. Fiksi merupakan hasil kontempelasi dan reaksi pengarang, lingkungan, dan kehidupan. Adapun tujuan penelitian ini yaitu untuk mengidentifikasi strategi bahasa yang mengandung prasangka dalam cerpen "Clara" karya Seno Gumira Ajidarma. Penelitian ini adalah penelitian deskriptif kualitatif. Data dalam penelitian ini adalah teks yang diambil dari cerpen "Clara" karya Seno Gumira Ajidarma. Analisis data dalam penelitian ini terdiri atas; (1) pengumpulan data berupa teks, yang dianggap menunjukkan prasangka dalam cerpen, dan (2) pengidentifikasian teks yang telah didapatkan berdasarkan ekspresi prasangka dan perangkat retoris. Hasil penelitian menunjukkan bahwa bahasa sastra dalam cerpen tidak terlepas dari prasangka. Tipe strategi bahasa yang digunakan adalah; repetisi, generalisasi, penunjukan kaum minoritas, dan penyebutan nama asal. Dari hasli penelitian terlihat bahwa semua tipe strategi bahasa baik itu repetisi, generalisasi, penunjukan kaum minoritas, maupun penyebutan nama asal cenderung digunakan untuk menunjukkan prasangka negatif.
\end{abstract}

Kata kunci: bahasa, prasangka, cerpen

\begin{abstract}
This study discusses social prejudice language in short story "Clara” by Seno Gumira Ajidarma. Prejudiced language is also found in literary works. Literary works as imaginary works usually offer human and humanity, life and life problems. The author lived up to these issues with a sincerity which was then expressed back through the means of fiction by his views. Fiction tells the various problems of human life and its interaction with the environment and neighbor. Fiction is the result of contemplation, the author's reaction and environment and life. The purpose of this study is to identify language strategies that contain prejudices in short story "Clara" by Seno Gumira Ajidarma. This research is qualitative descriptive research. The data in this study is the text taken from short story "Clara atawa Wanita yang Diperkosa" by Seno Gumira Ajidarma. Data analysis in this study consist of (1) data collection in the form of text which is considered to show prejudice from short stories, and (2) texts odentification that have been obtained based on the expression of prejudices and rhetorical devices. The results showed that the literary language in the short story could not be separated from prejudice. Type of language strategies used are; repetition, generalization, and the appointment of minorities. It
\end{abstract}


also shows that based on the data, all types of language strategies, repetition, generalization, minority appointments, and the name of origin tend to be used to denote negative prejudices.

Keywords: language, prejudice, short story

\section{Pendahuluan}

Isu SARA tidak akan pernah habis dibicarakan. Hal tersebut terlihat dengan masih banyaknya tuduhan penggunaan isu Sara di media sosial dan dalam kampanye politik. Penggunaan isu SARA dalam kampanye politik telah lama menarik perhatian. Pada tanggal 1 November 2016, di situs change.org muncul sebuah petisi dengan judul jangan rusak pilkada dengan isu SARA. Petisi yang ditujukan kepada Presiden Republik Indonesia ini memuat tuntutan untuk melarang penggunaan isu SARA dalam pilkada Jakarta maupun di daerah lainnya. Petisi yang didukung oleh perwakilan kelompok masyarakat diantaranya Yudi Latif, Benny Soestyo, Franz Magnis Suseno, Allisa Wahid. menunjukkan bahwa penggunaan isu SARA sebagai alat untuk melakukan propaganda politik sudah sampai pada tahap yang mengkhawatirkan. Hingga puncaknya pada tanggal 3 November 2016, Kementerian Komunikasi dan Informatika (Kemkominfo) melalui Direktorat Jenderal Aplikasi Informatika melayangkan surat pemberitahuan kepada penyedia jasa internet atau internet service provider (ISP) untuk memblokir sebelas situs yang dinilai memuat konten Suku, Agama, Ras dan Antargolongan (SARA).

AJI (Aliansi Jurnalistik Independen) Indonesia kemudian mempertanyakan keputusan pemblokiran sebelas situs tersebut. Keberatan AJI didasari oleh Pasal 19 DUHAM yang menyatakan bahwa setiap orang berhak atas kebebasan mempunyai dan mengeluarkan pendapat. Dalam hal ini termasuk kebebasan menyampaikan pendapat tanpa mendapat gangguan dan untuk mencari, menerima dan menyampaikan keterangan-keterangan serta pendapat dengan cara apa pun dan dengan tidak memandang batas-batas. Oleh karena itu, AJI meminta Kemkominfo untuk melakukan mekanisme pengujian atas keputusan pemerintah yang meminta ISP memblokir akses sebelas situs.

Permintaan AJI untuk melakukan mekanisme pengujian terhadap sebelas situs yang telah diblokir tersebut menjadi menarik sebab hingga saat ini mekanisme Kemkominfo dalam melakukan pemblokiran situs hanya didasari pada permintaan dari lembaga atau intansi pengawas yang terkait dan juga dari masyarakat. Dengan kata lain, pemblokiran suatu situs tertentu dapat dilakukan jika ada pihak-pihak yang keberatan dengan konten situs tersebut. Dengan demikian, jika pemblokiran suatu situs hanya didasari atas laporan masyarakat belum ada alat ukur yang pasti untuk menentukan apakah suatu situs mengandung konten yang bersifat SARA atau tidak. Penelitian ini penting dilakukan mengingat masih kurangnya model analisis bahasa dalam konteks tuturan yang mengandung prasangka sosial.

Tuturan yang mengandung isu SARA merupakan hasil dari adanya prasangka (Sarwono, 2007: 3-5). Prasangka adalah penilaian terhadap kelompok atau seorang individu yang terutama didasarkan pada keanggotaan kelompok tersebut, artinya prasangka ditujukan pada orang atau kelompok orang yang berbeda dengannya atau kelompoknya. Prasangka memiliki kualitas suka dan tidak suka pada obyek yang diprasangkainya, dan kondisi ini akan memengaruhi tindakan atau perilaku seseorang yang berprasangka tersebut.

Pengertian prasangka dibatasi sebagai sifat negatif yang tidak dapat dibenarkan terhadap suatu kelompok dan individu anggotanya (Worchel dkk., 2000: 45). Prasangka merupakan penilaian yang terlampau tergesa-gesa, berdasarkan generalisasi yang terlampau cepat, sifatnya berat sebelah dan dibarengi tindakan yang menyederhanakan suatu realitas (Kartono, 1981: 24). 
Prasangka (prejudice) adalah sebuah sikap (biasanya bersifat negatif) yang ditujukan bagi anggota-anggota beberapa kelompok, yang didasarkan pada keanggotaannya dalam kelompok (Sarwono dan Meinarno, 2009: 226). Menurut Sears (1994: 146) prasangka didefinisikan sebagai persepsi orang tentang seseorang atau kelompok lain, dan sikap serta perilakunya terhadap mereka. prasangka adalah orang atau kelompok lain, sikap tersebut didasarkan pada keanggotaan pada suatu kelompok. Prasangka merupakan suatu sikap sosial seseorang atau kelompok terhadap orang atau kelompok lain berupa penilaian negatif yang didasarkan pada keanggotaannya pada sustu kelompok sehingga seringkali tidak sesuai dengan kenyataan sesungguhnya (Alfandi, 2013: 120).

Individu yang berprasangka pada umumnya memiliki sedikit pengalaman pribadi dengan kelompok yang diprasangkai. Prasangka cenderung tidak didasarkan pada fakta objektif, tetapi didasarkan pada fakta yang minim yang diinterpretasi secara subjektif. Dalam hal ini prasangka melibatkan penilaian apriori karena memperlakukan objek sasaran prasangka tidak berdasarkan karakteristik unik atau khusus dari individu, tetapi melekatkan karakteristik kelompoknya yang menonjol (Tenriawali dan Aryana, 2016: 2).

Dalam definisi prasangka yang dikemukakan Brown (2005: 12) terdapat beberapa ciri prasangka, yaitu: (1) keyakinan kognitif yang bersifat merendahkan, (2) pengekpresian perasaan negatif, (3) tindakan permusuhan, dan (4) tindakan diskriminatif. Ciri-ciri prasangka yang dikemukakan Brown tersebut telah mencakup 3 (tiga) domain prasangka, yaitu keyakinan yang bersifat merendahkan merupakan domain kognitif, perasaan negatif merupakan domain afektif, sedangkan tindakan permusuhan dan diskriminasi merupakan domain konatif yang menurut penulis masih berupa kecenderungan untuk bertindak.

Pembagian jenis prasangka sosial didasarkan pada target yang menjadi sasaran prasangka. Ada beberapa target prasangka yang telah diidentifikasi dalam penelitian psikologi sosial, di antaranya sebagaimana menurut Susetyo (2010) sebagai berikut.

1. Ras dan etnis. Prasangka rasial adalah yang ditujukan pada kelompok ras atau etnis tertentu, seperti etnis Cina oleh warga pribumi di Indonesia.

2. Jenis kelamin. Prasangka jenis kelamin biasanya ditujukan kepada kaum perempuan. Misalnya perempuan tidak boleh mengemudi di Arab Saudi, perempuan tidak boleh bekerja di Afganistan, perempuan tidak boleh keluar negeri tanpa ijin suami di Sudan.

3. Homoseksual. Prasangka terhadap homoseksual seperti kaum gay dan lesbian. Prasangka terhadap homoseksual terjadi karena peran pria wanita tradisional yang didominasi oleh kaum heteroseksual.

4. Agama. Prasangka yang ditujukan pada pemeluk agama tertentu banyak terjadi di berbagai negara. Prasangka agama ini sering menimbulkan konflik berkepanjangan, sedangkan target prasangka agama juga tidak hanya kepada pemeluk agama lain saja, melainkan juga kepada sesama agama yang memiliki pemahaman atau organisasi keagamaan yang berbeda. Sebagai contoh prasangka agama yang terjadi di kalangan kelompok muslim, antara lain antara muslim tradisional dan modern, antara muslim moderat dan muslim liberal, antara muslim kultural dan muslim puritan.

Di lain hal, Van Dijk (1984: 112) mengatakan bahwa

Cognitive processes in the expression of prejudice in talk presuppose a complex system of social constraints, rules, norms, information, and situational variables. Among other things, talk, also in interviews, requires strategies of selfpresentation and persuasion.

Dari kutipan tersebut terlihat bahwa proses kognitif dalam (bahasa) ekspresi prasangka menunjukkan sistem sosial, aturan, norma, infomasi, dan situasi. Selain itu, ekspresi prasangka juga digunakan baik dalam percakapan ataupun wawancara yang menuntut strategi untuk menunjukkan diri dan 
juga memengaruhi orang yang diajak berbicara.

Pada dasarnya anggota masyarakat tahu mengenai aturan dan norma yang berlaku umum mengenai apa yang bisa dikatakan, kepada siapa, dan dalam situasi seperti apa. Dalam hal pembicaraan yang bersifat negatif, seperti gosip, fitnah, dan diskriminasi verbal, masyarakat cenderung memberi tanggapan dan penilaian yang buruk pada orang melakukan pembicaraan yang bersifat negatif tersebut, sehingga untuk menghindari penilaian buruk tersebut, orang yang ingin melakukan pembicaran yang bersifat negatif melakukan beberapa strategi berbahasa. Strategi berbahasa yang dimaksud di sini adalah gaya bahasa (stilistika) dalam mengungkapkan prasangka (Tenriawali dan Aryana, 2016: 3).

Stilistika, yakni ilmu tentang gaya bahasa, menjadi suatu disiplin ilmu yang mempelajari gaya-gaya bahasa. Sebenarnya, penggunaan dari gaya dan ilmu gaya itu secara luas meliputi seluruh aspek kehidupan manusia, bagaimana segala sesuatu dilakukan, dinyatakan, dan diungkapkan. Van Dijk (1984: 133) mengatakan bahwa

Style is the linguistic trace of the context in a text. More or less independently of content, style allows the hearer to infer properties of the personal or social characteristics of talk. In our case, for instance, stylistic variations allow the hearer to infer evaluation and affect involved in opinions and attitudes about minorities, about the social roles of the speaker, about the definition by the speaker of the ethnic relations involved, or about the actual strategies performed during the interview.

Kutipan di atas menunjukkan bahwa gaya adalah jejak linguistik dari suatu konteks yang berada di dalam teks. Gaya (bahasa) memungkinkan pendengar untuk menyimpulkan sifat karakteristik pribadi atau sosial orang yang berbicara, sehingga variasi gaya memungkinkan pendengar untuk menyimpulkan penilaian, pendapat, sikap pembicara tentang minoritas, tentang peran sosial dari pembicara, atau tentang strategi yang dilakukan oleh pembicara.
Menurut Van Dijk, strategi yang dilakukan pembicara untuk mengungkapkan prasangkanya meliputi Rhetorical operations (perangkat retoris) dan The expression of prejudice (ekspresi prasangka). The expression of prejudice terdiri atas; penunjukan kaum minoritas, penyebutan nama asal, penggunaan kata demonstratif jarak, paternalistic diminutive, serta penggunaan kata 'yang berbeda' (difference). Adapun Rhetorical operations terdiri atas; kontras (contrast), generalisasi, pernyataan yang melebihlebihkan, litotes, repetisi, penyebutan satu per satu dan klimaks, serta perbandingan.

\begin{tabular}{|c|c|}
\hline $\begin{array}{l}\text { The expression of } \\
\text { prejudice }\end{array}$ & Contoh \\
\hline $\begin{array}{l}\text { penunjukan kaum } \\
\text { minoritas }\end{array}$ & $\begin{array}{l}\text { Orang asing, orang cina, } \\
\text { yahudi, dll. }\end{array}$ \\
\hline $\begin{array}{l}\text { penyebutan nama } \\
\text { asal }\end{array}$ & $\begin{array}{l}\text { Negro, Surinamese, Turks, } \\
\text { Moroccans, dll }\end{array}$ \\
\hline $\begin{array}{l}\text { penggunaan kata } \\
\text { demonstratif jarak }\end{array}$ & $\begin{array}{l}\text { Orang asing itu, orang turki } \\
i t u \text {, orang-orang seperti itu, } \\
\text { dll }\end{array}$ \\
\hline $\begin{array}{l}\text { paternalistic } \\
\text { diminutive }\end{array}$ & $\begin{array}{l}\text { Penggunaan kata } \\
\text { perempuan yang seharusnya } \\
\text { wanita }\end{array}$ \\
\hline $\begin{array}{l}\text { Perbedaan } \\
\text { (Difference) }\end{array}$ & $\begin{array}{l}\text { Penggunaan kata seperti; } \\
\text { mereka } 4 \text { mempunyai } \\
\text { pemikiran yang berbeda, } \\
\text { mereka mempunyai gaya } \\
\text { hidup yang berbeda, } \\
\text { mereka mempunyai } \\
\text { kebiasaan yang berbeda, } \\
\text { mereka mempunyai } \\
\text { kepercayaan yang berbeda, } \\
\text { dll }\end{array}$ \\
\hline $\begin{array}{l}\text { Rhetorical } \\
\text { operations }\end{array}$ & Contoh \\
\hline Kontras & $\begin{array}{l}\text { Suami ku bekerja, } \\
\text { sedangkan mereka tidak }\end{array}$ \\
\hline Generalisasi & $\begin{array}{l}\text { Semua orang asing } \\
\text { membawa pisau }\end{array}$ \\
\hline Exaggeration & $\begin{array}{l}\text { Orang itu sanggup makan } \\
20 \text { porsi makanan dalam } \\
\text { sehari }\end{array}$ \\
\hline Litotes & $\begin{array}{l}\text { Kedudukan saya ini tidak } \\
\text { ada artinya sama sekali }\end{array}$ \\
\hline Repetition & $\begin{array}{l}\text { Very often, very often, I } \\
\text { have very good contacts } \\
\text { with them (foreigners), very } \\
\text { good contacts. }\end{array}$ \\
\hline $\begin{array}{l}\text { Enumeration and } \\
\text { Klimaks }\end{array}$ & $\begin{array}{l}\text { and that was not once, and } \\
\text { that was not twice, that was }\end{array}$ \\
\hline
\end{tabular}




\begin{tabular}{|l|l|}
\hline & constantly... \\
\hline Perbandingan & $\begin{array}{l}\text { foreigner is like a guest in } \\
\text { our house, who also must } \\
\text { adapt to the rules of the } \\
\text { house. }\end{array}$ \\
\hline
\end{tabular}

Prasangka atau prejudice merupakan perilaku negatif atau positif yang berdasar pada keterbatasan atau kesalahan informasi tentang kelompok. Prasangka yang juga dapat didefinisikan sebagai sesuatu yang bersifat emosional, akan mudah sekali menjadi motivasi munculnya ledakan sosial. Prasangka diwujudkan dengan ekspresi berbahasa. Bahasa atau tuturan yang menunjukkan prasangka terdapat dalam komik, karya sastra, buku teks, berita di media massa, propaganda politik, dan wacana (Van Dijk, 1984: 8).

Karya sastra sebagai karya imajiner yang biasanya menawarkan berbagai permasalahan manusia dan kemanusiaan, hidup dan kehidupan. Pengarang menghayati berbagai permasalahan tersebut dengan penuh kesungguhan yang kemudian diungkapkan kembali melalui sarana fiksi sesuai dengan pandangannya. Fiksi menceritakan berbagai masalah kehidupan manusia dan interaksinya dengan lingkungan dan sesama. Fiksi merupakan hasil kontempelasi dan reaksi pengarang dan lingkungan dan kehidupan (Nurgiantoro, 2010: 3). Oleh karena itu, penelitian ini akan menganalisis bahasa yang dianggap mengandung prasangka sosial dalam cerpen "Clara atawa Wanita yang Diperkosa" karya Seno Gumira Ajidarma. Penelitian terhadap bahasa prasangka menjadi menarik untuk dilakukan sebab dengan mengetahui prasangka yang terkandung di dalam wacana, maka akan diketahui bagaimana pandangan masyarakat/individu tersebut terhadap suatu permasalahan.

Pemilihan cerpen "Clara atawa Wanita yang Diperkosa" karya Seno Gumira Ajidarma sebagai objek penelitian disebabkan tema utama yang diangkat dalam cerpen tersebut adalah penindasan kaum mayoritas terhadap kaum minoritas. Berdasarkan pembacaan awal terhadap objek penelitian, peneliti menduga dalam cerpen tersebut terdapat bahasa prasangka. Adapun tujuan penelitian ini, yaitu mengidentifikasi bentuk kebahasaan prasangka yang terdapat dalam cerpen.
Penelitian mengenai bahasa prasangka pernah dilakukan oleh Darmojuwono dengan judul penelitian Manipulasi Bahasa dan Prasangka Sosial dalam Komunikasi. Dalam penelitian tersebut, Darmojuwono (2000: 3739) menyimpulkan bahwa manipulasi bahasa prasangka ditandai oleh beberapa hal, yaitu dengan; menggunakan kata-kata yang mengandung unsur makna emotif sehingga dapat menimbulkan emosi positif atau negatif, menggunakan kata-kata rancu maknanya atau tidak jelas sehingga memungkinkan perluasan atau penyempitan konsep sesuai dengan tujuan, mengaburkan konsep kata melalui eufemisme, dan menggunakan metafora sebagai cara mengungkap realitas secara tidak langsung. Tenriawali dan Aryana juga pernah meneliti tentang bahasa dan prasangka dalam media sosial. Hasil penelitian menunjukkan bahwa bahasa dalam media sosial tidak terlepas dari prasangka. Tipe gaya bahasa yang cenderung digunakan adalah generalisasi, kontras, repetisi, serta enumerasi dan klimaks. Penggunaan gaya bahasa tersebut bertujuan untuk menyakinkan pembaca bahwa apa yang diyakini oleh penulis status di media sosial tersebut adalah benar (Tenriawali dan Aryana, 2016: 1).

Berbeda dengan kedua penelitian relevan itu, penelitian ini menganalisis bentuk bahasa yang dianggap mengandung prasangka yang terdapat dalam karya sastra khususnya cerpen. Penelitian ini diharapkan dapat memberikan sumbangsih penelitian dalam bidang bahasa dan prasangka.

\section{Metode Penelitian}

Penelitian ini adalah penelitian deskriptif kualitatif. Penelitian kualitatif dengan metode deskriptif adalah penelitian yang mengidentifikasi, mengklarifikasi, menganalisis data yang telah diperoleh. Pendeskripsiannya berupa penggambaran bahasa sebagaimana adanya (Sudaryanto, 1993: 62).

Dengan demikian data dalam penelitian ini adalah teks yang diambil dari cerpen "Clara atawa Wanita yang Diperkosa" karya Seno Gumira Aji Darma. Analisis data dalam penelitian ini terdiri atas dua tahap, yaitu: (1) 
pengumpulan data berupa teks yang dianggap menunjukkan prasangka dari kumpulan cerpen, dan (2) pengidentifikasian teks yang telah didapatkan berdasarkan ekspresi prasangka dan perangkat retoris.

\section{Pembahasan}

Berikut merupakan cerpen "Clara atawa Wanita yang Diperkosa" karya Seno Gumira Ajidarma.

Clara atawa Wanita yang Diperkosa

Barangkali aku seorang anjing. Barangkali aku seorang babi*) - tapi aku memakai seragam. Kau tidak akan pernah tahu siapa diriku sebenarnya.

Di hadapanku duduk wanita itu. Rambutnya dicat merah. Coklat sebetulnya. Tapi orang-orang menyebutnya merah. Padahal merah punya arti lain bagiku. Sudah bertahun-tahun aku dicekoki pikiran bahwa orang-orang merah adalah orangorang yang berbahaya.

Jadi, aku tidak perlu percaya kepada wanita ini, yang rambutnya sengaja dicat merah. Barangkali isi kepalanya juga merah. Barangkali hatinya juga merah. Siapa tahu? Aku tidak perlu percaya kepada kata- kata wanita ini, meski ceritanya sendiri dengan jujur kuakui lumayan mengharukan.

Dia bercerita dengan bahasa yang tidak mungkin dimengerti. Bukan karena bahasa Indonesianya kurang bagus, karena bahasa itu sangat dikuasainya, tapi karena apa yang dialami dan dirasakannya seolah- olah tidak terkalimatkan. Wajahnya yang cantik sarat dengan luka batin yang tak terbayangkan. Aku hampirhampir terharu bahkan sebelum dia bercerita. Tidak pernah bisa kubayangkan bahwa manusia bisa mengalami beban penderitaan seberat itu justru karena dia lahir sebagai manusia. Ceritanya terpatah-patah. Kalimatnya tidak nyambung.

Kata-kata bertebaran tak terangkai sehingga aku harus menyambung-nyambungnya sendiri. Beban penderitaan macam apakah yang bisa dialami manusia sehingga membuatnya tak mampu berkata-kata?

Maka cerita yang akan kau dengar ini bukanlah kalimatnya melainkan kalimatku. Sudah bertahun-tahun aku bertugas sebagai pembuat laporan dan hampir semua laporan itu tidak pernah sama dengan kenyataan. Aku sudah menjadi sangat ahli menyulap kenyataan yang pahit menjadi menyenangkan, dan sebaliknya perbuatan yang sebetulnya patriotik menjadi subversif - pokoknya selalu disesuaikan dengan kebutuhan.

Maka, kalau cuma menyambung kalimat yang terputus-putus karena penderitaan, bagiku sungguh pekerjaan yang ringan.

$* * *$

Api sudah berkobar di mana-mana ketika mobil BMW saya melaju di jalan tol. Saya menerima telepon dari rumah. "Jangan pulang," kata Mama. Dia bilang kompleks perumahan sudah dikepung, rumah-rumah tetangga sudah dijarah dan dibakar. Papa, Mama, Monica, dan Sinta, adik-adikku, terjebak di dalam rumah dan tidak bisa ke mana-mana. "Jangan pulang, selamatkan diri kamu, pergilah langsung ke Cengkareng, terbang ke Singapore atau Hong Kong. Pokoknya ada tiket. Kamu selalu bawa paspor kan? Tinggalkan mobilnya di tempat parkir. Kalau terpaksa ke Sydney tidak apa-apa. Pokoknya selamat. Di sana kan ada Oom dan Tante," kata Mama lagi.

Saya memang sering ke luar negeri belakangan ini. Pontang-panting mengurusi perusahaan Papa yang nyaris bangkrut karena utangnya dalam dolar tiba-tiba jadi bengkak. Saya ngotot untuk tidak mem-PHK para buruh. Selain kasihan, itu juga hanya akan menimbulkan kerusuhan. Papa marah-marah. "Kita tidak punya uang untuk membayar buruh. Selain produksi sudah berhenti, yang beli pun kagak ada. Sekarang ini para buruh hidup dari subsidi perusahaan patungan kita di luar negeri. Mereka pun sudah mencak-mencak profitnya dicomot. Sampai kapan mereka sudi membayar orang-orang yang praktis sudah tidak bekerja?"

Saya masih ngotot. Jadi Papa putuskan sayalah yang harus mengusahakan supaya profit perusahaan patungan kami di Hong Kong, Beijing, dan Macao diperbesar. Tetesannya lumayan untuk menghidupi para buruh, meskipun produksi kami sudah berhenti. Itu sebabnya saya sering mondarmandir ke luar negeri dan selalu ada paspor di tas saya.

Tapi, kenapa saya harus lari sekarang, sementara keluarga saya terjebak seperti tikus di rumahnya sendiri? Saya melaju lewat jalan tol supaya cepat sampai di rumah. Saya memang mendengar banyak kerusuhan belakangan ini. Demonstrasi mahasiswa dibilang huru-hara. Terus terang saya tidak tahu persis apa yang terjadi. Saya terlalu tenggelam dalam urusan bisnis. Koran cuma saya baca judul-judulnya. Itu pun maknanya tidak pernah jelas. Namun, setidaknya saya yakin pasti bukan mahasiswa yang membakar dan menjarah kompleks perumahan, perkotaan, 
dan mobil-mobil yang lewat. Bahkan bukan mahasiswa pun sebenarnya tidak ada urusan membakar-bakari rumah orang kalau tidak ada yang sengaja membakar-bakar.

Saya tancap gas. BMW melaju seperti terbang. Di kiri kanan jalan terlihat api menerangi malam. Jalan tol itu sepi, BMW terbang sampai 120 kilometer per jam. Hanya dalam sepuluh menit saya akan segera tiba di rumah. Tapi, di ujung itu saya lihat segerombolan orang. Sukar sekali menghentikan mobil. Apakah saya harus menabraknya? Pejalan kaki tidak dibenarkan berdiri di tengah jalan tol, tapi saya tidak ingin menabraknya. Saya menginjak rem, tidak langsung, karena mobil akan berguling-guling. Sedikit-sedikit saya mengerem, dan toh roda yang menggesek aspal semen itu tetap mengeluarkan bunyi Ciiiiiiitttt! Yang sering dianggap sebagai petanda betapa para pemilik mobil sangat jumawa.

Setelah berhenti, saya lihat ada sekitar 25 orang. Semuanya laki-laki.

"Buka jendela," kata seseorang.

Saya buka jendela.

"Cina!" "Cina!" Mereka berteriak seperti menemukan intan berlian.

Belum sempat berpikir, kaca depan BMW itu sudah hancur karena gebukan. Aduh, benarkah sebegitu bencinya orang-orang ini kepada Cina? Saya memang keturunan Cina, tapi apa salah saya dengan lahir sebagai Cina? gemetar.

"Saya orang Indonesia," kata saya dengan

Braakk! Kap mobil digebuk. Seseorang menarik saya dengan kasar lewat jendela. Saya dilempar seperti karung dan terhempas di jalan tol.

"Sialan! Mata lu sipit begitu ngaku-ngaku orang Indonesia!" Pipi saya menempel di permukaan bergurat jalan tol. Saya melihat kakikaki lusuh dan berdaki yang mengenakan sandal jepit, sebagian tidak beralas kaki, hanya satu yang memakai sepatu. Kaki-kaki mereka berdaki dan penuh dengan lumpur yang sudah mengering.

"Berdiri!" Saya berdiri, hampir jatuh karena sepatu uleg saya yang tinggi. Saya melihat seseorang melongok ke dalam mobil. Membukabuka laci dashboard, lantas mengambil tas saya. Isinya ditumpahkan ke jalan. Berjatuhanlah dompet, bedak, cermin, sikat alis, sikat bulu mata, lipstik, HP, dan bekas tiket bioskop yang saya pakai nonton bersama pacar saya kemarin. Dompetnya segera diambil, uangnya langsung dibagi-bagi setengah rebutan. Sejuta rupiah uang cash amblas dalam sekejap. Tidak apa-apa. Mobil masih bisa dikendarai dengan kaca pecah, dan saya tidak perlu uang cash. Di dalam dompet ada foto pacar saya. Orang yang mengambil dompet tadi mengeluarkan foto itu, lantas mendekati saya.

"Kamu pernah sama dia?"

Saya diam saja. Apa pun maksudnya saya tidak perlu menjawabnya.

Plak! Saya ditampar. Bibir saya perih. Barangkali pecah.

"Jawab! Pernah kan? Cina-cina kan tidak punya agama!" Saya tidak perlu menjawab.

Bug! Saya ditempeleng sampai jatuh.

Seseorang yang lain ikut melongok foto itu.

"Huh! Pacarnya orang Jawa!" Saya teringat pacar saya. Saya tidak pernah peduli dia Jawa atau Cina, saya cuma tahu cinta.

"Periksa! Masih perawan atau tidak dia!" Tangan saya secara refleks bergerak memegang rok span saya, tapi tangan saya tidak bisa bergerak. Ternyata sudah ada dua orang yang masing-masing memegangi tangan kanan dan tangan kiri saya. Terasa rok saya ditarik. Saya menyepak-nyepak. Lagi-lagi dua pasang tangan menangkap kedua kaki saya.

"Aaaahhh! Tolongngng!" Saya menjerit. Mulut saya dibungkam telapak kaki berdaki. Wajah orang yang menginjak mulut saya itu nampak dingin sekali. Berpuluh-puluh tangan menggerayangi dan meremas-remas tubuh saya.

"Diem lu Cina!" Rok saya sudah lolos....

***

Wanita itu menangis. Mestinya aku terharu. Mestinya. Setidaknya aku bisa terharu kalau membaca roman picisan yang dijual di pinggir jalan. Tapi, menjadi terharu tidak baik untuk seorang petugas seperti aku. Aku harus mencatat dengan rinci, objektif, deskriptif, masih ditambah mencari tahu jangan-jangan ada maksud lain di belakangnya. Aku tidak boleh langsung percaya, aku harus curiga, sibuk menduga kemungkinan, sibuk menjebak, memancing, dan membuatnya lelah supaya cepat mengaku apa maksudnya yang sebenarnya. Jangan terlalu cepat percaya kepada perasaan. Perasaan bisa menipu. Perasaan itu subjektif. Sedangkan aku bukan subjek di sini. Aku cuma alat. Aku cuma robot. Taik kucing dengan hati nurani. Aku hanya petugas yang membuat laporan, dan sebuah laporan harus sangat terinci bukan?

"Setelah celana dalam kamu dicopot, apa yang terjadi?"

Dia menangis lagi. Tapi masih bercerita dengan terputus-putus. Ternyata susah sekali menyambung-nyambung cerita wanita ini. Bukan 
hanya menangis. Kadang-kadang dia pingsan. Apa boleh buat, aku harus terus bertanya.

"Saya harus tahu apa yang terjadi setelah celana dalam dicopot, kalau kamu tidak bilang, apa yang harus saya tulis dalam laporan?"

$* * *$

Saya tidak tahu berapa lama saya pingsan. Waktu saya membuka mata, saya hanya melihat bintang-bintang. Di tengah semesta yang begini luas, siapa yang peduli kepada nasib saya? Saya masih terkapar di jalan tol. Angin malam yang basah bertiup membawa bau sangit. Saya menengok dan melihat BMW saya sudah terbakar. Rasanya baru sekarang saya melihat api dengan keindahan yang hanya mewakili bencana. Isi tas saya masih berantakan seperti semula. Saya melihat lampu HP saya berkedip-kedip cepat, tanda ada seseorang meninggalkan pesan.

Saya mau beranjak, tapi tiba-tiba selangkangan saya terasa sangat perih. Bagaikan ada tombak dihunjamkan di antara kedua paha saya. O, betapa pedihnya hati saya tidak bisa saya ungkapkan. Saya tidak punya kata-kata untuk itu. Saya tidak punya bahasa. Saya hanya tahu bahasa Indonesia dan bahasa Inggris untuk urusan bisnis. Kata orang, bahasa Cina sangat kaya dalam hal menggambarkan perasaan, tapi saya tidak bisa bahasa Cina sama sekali dari dialek manapun, kecuali yang ada hubungannya dengan hargaharga. Saya cuma seorang wanita Cina yang lahir di Jakarta dan sejak kecil tenggelam dalam urusan dagang. Saya bukan ahli bahasa, bukan pula penyair. Saya tidak tahu apakah di dalam kamus besar Bahasa Indonesia ada kata yang bisa mengungkapkan rasa sakit, rasa terhina, rasa pahit, dan rasa terlecehkan yang dialami seorang wanita yang diperkosa bergiliran oleh banyak orang -karena dia seorang wanita Cina. Sedangkan pacar saya saja begitu hati-hati bahkan hanya untuk mencium bibir saya. Selangkangan saya sakit, tapi saya tahu itu akan segera sembuh. Luka hati saya, apakah harus saya bawa sampai mati? Siapakah kiranya yang akan membela kami? Benarkah kami dilahirkan hanya untuk dibenci?

Saya tidak bisa bergerak sampai seorang ibu tua datang terbungkuk-bungkuk. Dia segera menutupi tubuh saya dengan kain.

"Maafkan anak-anak kami," katanya, "mereka memang benci dengan Cina."

Saya tidak sempat memikirkan arti kalimat itu. Saya bungkus tubuh saya dengan kain, dan tertatih-tatih menuju tempat di mana isi tas saya berserakan. Saya ambil HP saya, dan saya dengar pesan Papa: "Kalau kamu dengar pesan ini, mudah-mudahan kamu sudah sampai di Hong
Kong, Sydney, atau paling tidak Singapore. Tabahkanlah hatimu Clara. Kedua adikmu, Monica dan Sinta, telah dilempar ke dalam api setelah diperkosa. Mama juga diperkosa, lantas bunuh diri, melompat dari lantai empat. Barangkali Papa akan menyusul juga. Papa tidak tahu apakah hidup ini masih berguna. Rasanya Papa ingin mati saja."

$* * *$

Dia menangis lagi. Tanpa airmata. Kemudian pingsan. Kudiamkan saja dia tergeletak di kursi. Ia hanya mengenakan kain. Seorang ibu tua yang rumahnya berada di kampung di tepi jalan tol telah menolongnya. "Dia terkapar telanjang di tepi jalan," kata ibu tua itu. Aku sudah melaporkan soal ini kepada pimpinanku. Lewat telepon dia berteriak, "Satu lagi! Hari ini banyak sekali perkara beginian.

Tahan dia di situ. Jangan sampai ada yang tahu. Terutama jangan sampai ketahuan wartawan dan LSM!" Pesuruh kantor membaukan PPO ke hidungnya. Matanya melek kembali.

"Jadi kamu mau bilang kamu itu diperkosa?"

Dia menatapku.

"Padahal kamu bilang tadi, kamu langsung pingsan setelah ... apa itu ... rok kamu dicopot?"

Dia menatapku dengan wajah tak percaya.

"Bagaimana bisa dibuktikan bahwa banyak orang memperkosa kamu?"

Kulihat di matanya suatu perasaan yang tidak mungkin dibahasakan. Bibirnya menganga. Memang pecah karena terpukul. Tapi itu bukan berarti wanita ini tidak menarik. Pastilah dia seorang wanita yang kaya. Mobilnya saja BMW. Seorang wanita eksekutif. Aku juga ingin kaya, tapi meskipun sudah memeras dan menerima sogokan di sana-sini, tetap begini-begini saja dan tidak pernah bisa kaya. Naik BMW saja aku belum pernah. Aku memang punya sentimen kepada orang-orang kaya -apalagi kalau dia Cina. Aku benci sekali. Yeah. Kainnya melorot, dan tampaklah bahunya yang putih....

"Jangan terlalu mudah menyebarkan isyu diperkosa. Perkosaan itu paling sulit dibuktikan. Salah-salah kamu dianggap menyebarkan fitnah."

Di matanya kemarahan terpancar sekejap. Bahwa dia punya nyali untuk bercerita, memang menunjukkan dia wanita yang tegar.

"Saya mau pulang," ia berdiri. Ia hanya mengenakan kain yang menggantung di bahu. Kain itu panjangnya tanggung, kakinya yang begitu putih dan mulus nampak telanjang.

"Kamu tidur saja di situ. Di luar masih rusuh, toko-toko dibakar, dan banyak perempuan Cina diperkosa." 
"Tidak, saya mau pulang."

"Siapa mau mengantar kamu dalam kerusuhan begini. Apa kamu mau pulang jalan kaki seperti itu? Sedangkan pos polisi saja di mana-mana dibakar."

Dia diam saja.

"Tidur di situ," kutunjuk sebuah bangku panjang, "besok pagi kamu boleh pulang."

Kulihat dia melangkah ke sana. Dalam cahaya lampu, lekuk tubuhnya nampak menerawang. Dia sungguh-sungguh cantik dan menarik, meskipun rambutnya dicat warna merah. Rasanya aku juga ingin memperkosanya. Sudah kubilang tadi, barangkali aku seorang anjing, barangkali aku seorang babi — tapi aku mengenakan seragam. Kau tidak akan pernah tahu siapa diriku sebenarnya. Masalahnya: menurut ilmu hewan, katanya binatang pun tidak pernah memperkosa.

Tentu saja tentang yang satu ini tidak perlu kulaporkan kepada pimpinan. Hanya kepadamu aku bisa bercerita dengan jujur, tapi dengan catatan - semua ini rahasia. Jadi, jangan bilangbilang.

\section{Jakarta, 26 Juni 1998}

(www.sukab.wordpress.com)

Berikut merupakan penjelasan teks yang dianggap mengandung bahasa prasangka sosial.

\subsection{Repetisi}

Repetisi termasuk ke dalam jenis perangkat retoris (rhetorical operation). Repetisi merupakan salah satu strategi yang digunakan seseorang untuk menyatakan prasangkanya. Kalimat prasangka yang mengandung repetisi terdapat pada data berikut.

1. Barangkali aku seorang anjing. Barangkali aku seorang babi*) - tapi aku memakai seragam. Kau tidak akan pernah tahu siapa diriku sebenarnya.

2. Jadi, aku tidak perlu percaya kepada wanita ini, yang rambutnya sengaja dicat merah. Barangkali isi kepalanya juga merah. Barangkali hatinya juga merah. Siapa tahu? Aku tidak perlu percaya kepada kata- kata wanita ini, meski ceritanya sendiri dengan jujur kuakui lumayan mengharukan.

3. Aku cuma alat. Aku cuma robot. Taik kucing dengan hati nurani.
Kata barangkali aku pada kalimat 1, kata barangkali pada kalimat 2, dan kata aku pada kalimat 3 menjadi penanda linguistik strategi repetisi.

Dalam konteks kalimat 1, penggunaan kata barangkali aku sebagai piranti linguistik repetisi merujuk pada prasangka negatif yang dimiliki petugas polisi penginterogasi Clara pada dirinya sendiri yang menyamakan dirinya dengan binatang. Petugas polisi yang menginterogasi Clara ini menjadi narator internal yang menceritakan watak dirinya yang seperti anjing dan babi. Kata anjing dan babi di masyarakat Indonesia pada umumnya digunakan sebagai kata umpatan yang sangat kasar, sehingga penggunaan kata anjing dan babi menunjukkan prasangka negatif petugas polisi tersebut yang mengidentifikasi dirinya memiliki kesamaan dengan anjing dan babi.

Dalam konteks kalimat 2, penggunaan kata barangkali sebagai piranti linguistik penanda repetisi menunjukkan bahwa petugas polisi yang menginterogasi Clara tidak percaya dengan kata-kata Clara. Pengulangan kata barangkali pada kalimat 2 bertujuan menunjukkan kecurigaan polisi yang menganggap Clara komunis. Hal tersebut terlihat dalam teks Barangkali isi kepalanya juga merah. Barangkali hatinya juga merah. Kata barangkali dalam konteks kalimat ini juga mengandung makna meragukan ataupun sesuatu yang tidak pasti.

Adapun dalam konteks kalimat 3, pengulangan kata aku menunjukkan petugas polisi menganggap dirinya hanya sebagai alat sehingga petugas polisi tersebut memiliki prasangka negatif bahwa dirinya tidak memiliki hati nurani. Penggunaan kata aku dalam kalimat ini yang dirangkaikan dengan kata alat dan robot makin memperkuat kesan pemaknaan bahwa petugas polisi tersebut hanya benda mati yang ditugaskan untuk mencatat pengakuan Clara.

\subsection{Generalisasi}

Generalisasi merupakan salah satu jenis strategi perangkat retoris. Penggunaan generalisasi untuk menyatakan penilaian atau anggapan baik atau buruk, biasanya didasari oleh prasangka baik atau buruk perihal 
gagasan atau simpulan umum dari suatu kejadian, hal, dan sebagainya. Data bahasa yang mengandung generalisasi terdapat dalam kalimat berikut.

Sudah bertahun-tahun aku dicekoki pikiran bahwa orang-orang merah adalah orang-orang yang berbahaya (Cerpen "Clara")

Penggunaan kata orang merah adalah orangorang yang berbahaya pada kalimat di atas menunjukkan bahwa petugas polisi yang mewawancarai Clara menggeneralisasi orangorang merah, yang dalam konteks kalimat ini yaitu orang komunis, semuanya dianggap berbahaya.

\subsection{Penunjukan Kaum Minoritas}

Penunjukan kaum minoritas tergolong ke dalam strategi ekspresi prasangka (The expression of prejudice). Penunjukan kaum minoritas biasanya ditandai dengan pelabelan yang merujuk pada sesuatu. Penggunaan penunjukan kaum minoritas cenderung mengandung prasangka negatif. Penunjukan kaum minoritas terdapat dalam kalimat berikut.

1. "Cina!" "Cina!" Mereka berteriak seperti menemukan intan berlian.

2. "Kamu pernah sama dia?"

Saya diam saja. Apa pun maksudnya saya tidak perlu menjawabnya.

Plak! Saya ditampar. Bibir saya perih. Barangkali pecah.

"Jawab! Pernah kan? Cina-cina kan tidak punya agama!" Saya tidak perlu menjawab.

3. "Diem lu Cina!" Rok saya sudah lolos....

4. "Maafkan anak-anak kami," katanya, "mereka memang benci dengan Cina."

Dalam keempat kalimat di atas, yang menjadi penanda strategi penunjukan kaum minoritas adalah kata Cina. Penggunaan kata Cina dalam keempat kalimat di atas menunjukkan bahwa kata Cina memiliki makna negatif. Kata Cina identik dengan etnis tertentu yang dianggap memiliki sifat-sifat buruk. Hal tersebutlah yang menjadikan penduduk lokal (pribumi) memiliki prasangka negatif pada orang-orang Cina.

\subsection{Penyebutan Nama Asal}

Penyebutan nama asal termasuk ke dalam strategi ekspresi prasangka. Penggunaan strategi penyebutan nama asal cenderung dilakukan untuk memberikan pemaknaan tertentu pada daerah asal atau suku tertentu. Dalam cerpen, teks yang menunjukkan strategi penyebutan nama asal terdapat dalam kalimat berikut.
"Huh! Pacarnya orang Jawa!" Saya teringat pacar saya. Saya tidak pernah peduli dia Jawa atau Cina, saya cuma tahu cinta. (Cerpen "Clara")

Pada kalimat itu, kata Jawa menjadi penanda linguistik untuk strategi penyebutan nama asal. Kata orang Jawa dalam konteks kalimat tersebut memiliki anggapan negatif karena orang Jawa adalah penduduk lokal, sehingga tidak mungkin menyukai Clara yang beretnis cina. Dari perspektif masyarakat umum kata orang Jawa juga menunjukkan orang pribumi yang identik dengan sesuatu yang sangat menjunjung tinggi tradisi atau mencintai budayanya sehingga dalam konteks kalimat tersebut pacar tokoh Clara yang orang jawa tersebut dianggap tidak mungkin meninggalkan identitas budayanya sebagai orang Jawa dan menjadi pacar tokoh Clara. Oleh karena itu, kata orang Jawa dalam kalimat di atas mengandung prasangka negatif dari para pelaku penyerangan Clara.

Berdasarkan data kebahasaan yang menjadi penanda repetisi, generalisasi, penunjukan kaum minoritas, dan penyebutan nama asal terlihat bahwa data dalam keempat strategi tersebut menunjukkan prasangka negatif yang berjenis prasangka etnis dan ras atau prasangka rasial. Prasangka rasial inilah yang menjadi tema cerpen Clara ini.

Cerpen Clara menggambarkan sebuah sisi kejadian yang terjadi pada masa peralihan tampuk pimpinan dari masa Orde Baru menuju masa reformasi. Dalam cerpen tersebut terdapat pemaknaan identitas, nasionalisme keindonesiaan, serta nuansa pribumi dan nonpribumi. Seno Gumira Ajidarma berusaha menggambarkan kisah tragedi Mei 1998 melalui tokoh Clara. Tokoh Clara yang memiliki ciri-ciri fisik berkulit putih dan 
bermata sipit dalam cerpen diberi pelabelan cina yang bertujuan untuk memarginalkan tokoh Clara karena etnis cina tidak termasuk orang pribumi. Berbeda dengan sang petugas dan sang pemerkosa dengan segala ciri-cirinya mewakili posisi pribumi di dalamnya, karena sang petugas adalah orang yang berwenang menerima laporan dari warga negara dan wajib melaporkannya kepada atasnya meski dia melaporkannya disesuaikan dengan kebutuhan. Adapun para pemerkosanya, mewakili kaum pribumi kelas bawah dengan gambaran kakikaki lusuh dan berdaki yang hanya mengenakan sandal jepit, sebagian besar tidak beralas kaki, hanya satu yang memakai sepatu. Kaki-kaki mereka berdaki dan penuh dengan lumpur yang sudah mengering. Sehingga penggunaan strategi repetisi, generalisasi, penunjukan kaum minoritas, dan penyebutan nama asal yang mengandung prasangka negatif makin memperkuat nuansa perbedaan pribumi dan non pribumi dalam cerpen tersebut.

Oleh karena itu, prasangka sosial yang paling dominan dalam cerpen Clara ini adalah prasangka rasial yang ditunjukkan dengan penggunaan bahasa yang mengandung strategi repetisi, generalisasi, penunjukan kaum minoritas, dan penyebutan nama asal. Penggunaan kata-kata yang dianggap mengandung prasangka negatif dalam cerpen mendukung tema umum cerpen ini yaitu tentang kisah kerusuhan Mei 1998. Tema tentang ketidakadilan, penderitaan, perjuangan, dan ketidakberdayaan yang dialami tokoh Clara makin diperkuat dengan penggunaan kata atau bahasa yang menunjukkan prasangka negatif.

\section{Simpulan}

Dari hasil analisis dapat disimpulkan bahwa bahasa sastra dalam cerpen tidak terlepas dari prasangka. Tipe strategi bahasa yang digunakan adalah: repetisi, generalisasi, penunjukan kaum minoritas dan penyebutan nama asal.

Dari hasil penelitian juga terlihat bahwa berdasarkan data yang ditemukan, semua tipe strategi bahasa baik itu repetisi, generalisasi, penunjukan kaum minoritas, maupun penyebutan nama asal cenderung digunakan untuk menunjukkan anggapan atau pendapat negatif. Oleh karena itu, strategi repetisi, generalisasi, penunjukan kaum minoritas, dan penyebutan nama asal dalam cerpen "Clara" karya Seno Gumira Aji Darma hanya menunjukkan prasangka negatif.

\section{Daftar Pustaka}

Alfandi, M. (2013). "Prasangka: Potensi pemicu konflik internal umat islam". Jurnal Walisongo, 21(1). hal 120-135.

Baron, A. Robert \& Byrne, Donn.(1991). Social Psychology. London: Allyn and Bacon.

Brown, R. (2005). Prejudice: Menangani Prasangka dari Perspektif Psikologi Sosial. Yogyakarta: Pustaka Pelajar.

Kartono, Kartini. (1981). Patologi Sosial Jilid I. Bandung: Rajawali Press.

Kuncoro, Joko. (2012). 'Prasangka dan Diskriminasi'. Makalah. Semarang: Fakultas Psikologi UNISSULA.

Nurgiyantoro, Burhan. (2010). Teori Pengkajian Fiksi. Yogyakarta: Gadjah Mada University Press.

Sarwono S.W., Meinarno E.A. (ed.), (2009). Psikologi Sosial. Jakarta: Salemba Humanika.

Sarwono, Salito Wirawan. (2007). Psikologi Prasangka Orang Indonesia. Jakarta: PT RajaGrafindo Persada.

Sears D. O. (1994). Psikologi Sosial Jilid II. Jakarta: Erlangga,

Soekanto, Soerjono. (1999). Sosiologi Suatu Pengantar. Jakarta: PT. RajaGrafindo Persada.

Sudaryanto. (1993). Metode dan Aneka Teknik Analisis Bahasa: Pengantar Penelitian Wahana Kebudayaan Secara Linguistik. Yogyakarta: Duta Wacana University Press.

Sukab. (28 April 2018). Clara atawa Wanita yang Diperkosa. Diperoleh dari www.sukab.wordpress.com

Susetyo, D.P.B. (2010). Stereotip dan Relasi Antar Kelompok. Yogyakarta: Graha Ilmu.

Tenriawali, A. Yusdianti., \& Aryana, A. (2016). 'Bahasa dan Prasangka dalam 
Media Sosial'. Prosiding Seminar Nasional Bulan Bahasa, Universitas Hasanuddin. Vol. 1, No. 1. hal 45-55.

Teun A. van Dijk. (1984). Prejudice in discourse. Amsterdam/Philadelphia: John Benjamins Publishing Company.

Worchel, S., Cooper, R., Goethals, G. R., \& Olson, J.M. (2000). Social Psychology. USA: Thomson Learning. 